\title{
DEVELOPMENT OF CRITICAL THINKING SKILLS THROUGH DISTANCE LEARNING IN DEVELOPING COUNTRIES
}

\author{
Prof. Neltile van Wyk \\ Head, Department of Nursing Science, University of Pretoria \\ Correspondence: nursing@medic.up.ac.za
}

Keywords: distance education and learning; developing countries; critical thinking skills

\begin{abstract}
Interpersonal contact between the lecturers and students improves the development of critical thinking skills. The process is hampered by the geographical distance between the lecturers and the students in the case of distance education and learning. In many cases distance learning is, however, the only option. The distance can successfully be overcome through careful planning of contact opportunities between the lecturers and students. The development of critical thinking skills through distance education and learning is thus possible through the commitment of both the lecturers and the students.
\end{abstract}

\section{OPSOMMING}

Interpersoonlike kontak tussen dosente en studente bevorder die ontwikkeling van kritiese denkvaardighede. Met die geografiese afstand tussen dosente en studente in die geval van afstandsonderrig en leer word die proses bemoeilik. In baie omstandighede is afstandsleer egter die enigste keuse vir studente. Deur deeglike beplanning van kontakgeleenthede tussen dosente en studente kan die afstand suksesvol oorbrug word. Met die toewyding van beide die dosente en die studente is die ontwikkeling van kritiese denkvaardighede deur afstandsonderrig en leer dus wel moontlik.

\section{INTRODUCTION}

Distance learning does not only imply a geographical distance between the learner and the providing institution, but also widens access opportunities for education to individuals who on a daily basis, have to cope with substantial professional, employment and domestic commitments (Ayer \& Smith, 1998:1034; Von Prummer, 1994:3). As it can be tailored to meet individual learning needs and provides a flexible learning option, it is convenient to the student (Laidlaw \& Harden, 1990:9). This feature of distance learning makes it an increasingly attractive continuing professional development option for health workers, including physicians and nurses (Rogerson \& Harden, 1999:287).

The emphasis of distance learning in nursing is, however, not only focused on meeting the diverse needs of the prospective student, but also on accommodating the demands of the work situation of the student and in ensuring that the services in the particular hospital or clinic will not be jeopardised by the absence of the nurse who is busy with further training (Ayer \& Smith, 1998:1034; Rogerson \& Harden, 1999:287). This is especially important for nurses in rural areas. Health care facilities usually strongly support educational programs that facilitate the student who remains in the rural setting (Leasure, Davis \& Thievon, 2000:149). Not only will the service delivery not be involved, but the rural nurses who studied by means of distance education tend to remain in the rural community following completion of their studies, while those who relocated for study purposes usually do not (Shomaker \& Fairbank, 1997:328). It is therefore seen as an important recruitment and retention mechanism for hospitals in the rural areas. While hospitals manage to retain the nurses, the nurses get the opportunity to study and obtain post-registration qualifications. The demand for more nurses prepared to fulfill advanced roles in the community hospitals and clinics are thus met (Reinert \& Fryback, 1997:424).

Similar to the rest of the world, distance education in 
developing countries is an option for post-registration courses only (Tait, 1994:27). It is also more suitable for non-clinical courses than for clinical courses. In case of the latter, too much clinical work and development of clinical skills included in such courses make it difficult to manage the courses without direct contact with the students. Visits by the lecturers to the hospitals once or twice per year will not ensure enough time for the training of skilled practitioners. Hopper (2000:434) is very specific by saying that the truly valuable learning that takes place ... does not occur in the classroom at all, distant or traditional, but in the physical presence of a master practitioner'. While the theoretical part of a clinical course can be handled by distance education, the practical part of the course need to be presented in the ward, clinic or unit in the presence of a skilled person. In many rural hospitals and clinics skilled practitioners who can act as mentors and preceptors are not available with the result that such clinical courses cannot be presented. According to the White Paper on Distance Education of the AACN (2000:118) the development of behavioral skills will have to continue in the traditional way but with increased flexibility to make the courses accessible for students of rural areas. Various options will have to be investigated. If a member of the faculty is willing to relocate for a year or two, a satellite campus can be developed. She/he takes responsibility for the practical training of the students in the vicinity of the satellite-campus while the theoretical part of the course is then presented by means of interactive television technology (Lia-Hoagberg, Vellenga, Miller \& Tao-Yuan, 1999:117). After the period of two years enough people might be trained to do the work that is expected from them in the hospitals and clinics. If there is still a need to continue with training, the already-trained nurses can act as preceptors and mentors for the students. Regular visits by the faculty are necessary to ensure a high quality of training following departure of the temporary lecturer.

\section{PURPOSE OF THE ARTICLE}

The purpose of this article is to debate the possibility that the development of critical thinking skills of the students in non-clinical courses can be supported through distance education.

\section{TYPES OF DISTANCE EDUCATION AND ITS SUITABILITY FOR DEVELOPING}

\section{COUNTRIES}

Various types of distance education have been developed, some of them more and others less suitable for interactive learning. Hopper (2000:432) summarised the variety of distance education options as either:

- different time/different place options, such as postal or asynchronous on-line courses, or

- $\quad$ same time/different place options, such as synchronous broadcast (one-way or two-way) courses.

Included in this summary are correspondence classes, audio and video tapes, satellite television, cable television, computers, teleconferencing, interactive and compressed video, and faculty travel (Reinert \& Fryback, 1997:424). The latter represents the first type of distance education used. However, it still has a place in the whole scenario of the delivery of distance education as it makes interactive education possible and serves as an important support measure for distant students.

Teaching through correspondence only is the least suitable method for interactive learning, as it does not allow any interaction with the faculty or fellow students although in many cases it is the only affordable option for studying in rural areas. However, many people consider it as a good way of administering distance education as it is cheap. Only a postal service is required to effectively manage the process. Students receive their study material by post, send the assignments back in the same manner and write the necessary examinations in the hospital or clinic under the supervision of one of his/her supervisors. What the student really gains through such an experience is questionable as no professional socialisation takes place. Where there is a lack of infrastructure, as in the case of developing countries, this option of distance education is an easy solution to the problem of lack of higher education opportunities.

To choose a method of distance education due to the fact that it is cheap, is not acceptable. Institutions responsible for distance education have the obligation to deliver services of high quality and have to look for affordable, but still effective options. Good distance education is not cheap. Murphy (1995:1016) is of the opinion that it is not even cheaper than campus-based education. 
An affordable option in distance education that allows interaction between the faculty and students, as well as between students and fellow students, is interactive television courses (Reilly, 1998:40). It allows students to study without having to relocate and at the same time has the advantage of interaction with the lecturer during a broadcast (Tagg \& Arreola, 1996:157). In this manner all the students benefit from the broadcast, as all of them can interact with the lecturer as well as with their fellow students. Distant and on-campus students are treated equally and feel part of one group so that the distance education students will not feel isolated (Reilly, 1998:40). According to Edwards, Hugo, Cragg \& Peterson (1999:40), it is even possible to make use of a problembased approach as the lecturer is in contact with all the students during the conference. They found that audioteleconferencing helped the students to be more selfdirected, to be able to work in a group and to make full use of the problem-based approach.

On-line teaching in distance education in nursing opens a whole new range of advantages and possibilities in interactive teaching. However, for prospective students in developing countries it is still a dream. Not only is it too expensive, but it is also not accessible to people who are not computer literate. Not all the hospitals and clinics in developing countries are equipped with computers. Development of computer programs for post-registration training of nurses in developing countries will therefore benefit only a small portion of the population.

Nurses working in hospitals and clinics in the rural areas of developing countries are isolated. They do not have many opportunities to interact with colleagues from other institutions. Contributing to the isolation is the lack of infrastructure that they have to cope with. To overcome this hurdle and to help them gain not only knowledge, but also to develop reflective thinking skills required for their professional development, asks for a lot of creativity from the institutions responsible for distant education in developing countries. Interaction with faculty and fellow students is non-negotiable. Without the support that they receive in this way, professional development will be very difficult if not impossible.

One of the positive factors is the ability of nurses in developing countries to work independently. They are exposed to situations in which they have to cope without the support that nurses in developed countries have in the form of either nursing colleagues or physicians. Selfstudy as such does not pose a problem to them. This makes it easier for them to adapt to a distance education course. Memorising facts so that it can be described during evaluation will, however, not be beneficial to their professional development or to the patients they care for. They need assistance with the development of higherorder cognitive skills such as critical thinking and clinical decision-making (Edwards, Hugo, Cragg \& Peterson, 1999:36). This cannot be done through a correspondence distance education course without any contact with lecturers and fellow students. A combination of self-study and contact with the faculty by means of a well-developed and well-structured distance education course is the answer for the great number of nurses in developing countries who are in desperate need for post-registration education and training. According to Sullivan (2000:186), making use of a combination of options and techniques in education and training will enable responsible nurse lecturers to use distance education and to retain control over the practice preparation of the students.

\section{DEVELOPMENT OF CRITICAL THINKING SKILLS IN DISTANCE EDUCATION}

Nurses in developing countries have to cope with limited resources and growing responsibilities to a greater extent than their colleagues in developed countries. At the same time they have to adapt to the development in science and technology in medicine as well as nursing as is the case with nurses all over the world. Nurses in developing countries thus need special skills in order to keep on rendering high quality nursing care. According to Jacobs, Ott, Sullivan, Ulrich and Short (1997:19) one way of ensuring this is the development of critical thinking skills.

Many definitions of critical thinking is available of which the following one by Bandman \& Bandman (1995) is highly descriptive:"Critical thinking is the repeated examination of problems, questions, issues, and situations by comparing, simplifying, synthesizing information in an analytical deliberative, evaluative, decisive way" (in Jacobs et al. 1997:20).

Interaction between the student, lecturer and fellow students is necessary in order to support nurses during training to develop such skills. For thinking to be critical, 
our ideas, bellefs, and actions must be validated through discourse with others (Garrison, 1992:136).

People, and therefore also nurses, are not critical thinkers by nature. The opposite is unfortunately true. According to Berry and Dienes (1993) "humans tend to construct mental images of their experiences either consciously and with effort or in the case of repeated everyday experiences, relatively unconsciously and effortlessiy" (in Greenwood, Sullivan, Spence \& McDonald, 2000:1107). This is done for biological and social survival so that when similar situations are encountered the human mind will recognise the similarity and will react automatically (Greenwood, 1996:1). With repeated coactivation of 'stimulus' and 'response' concepts their progressive thinking becomes less and less conscious until automaticity is reached (Greenwood et al. 2000:1107). At this point in time humans act without thinking and no longer ask whether what they do is acceptable or good. This happens very often in nursing. Nurses in some cases do as they have been told without considering whether what they have done was the best possible action in the particular circumstances. 'Think while you do' is discouraged by repeated action (Powell, 1989:826). 'Think while you do' can create insecurity, as the person then has to take responsibility for what has been done. Resorting to routinised nursing practices protect the nurse from taking risks associated with individualised clinical decisions (Greenwood et al. 2000:1107).

Therefore, it is the responsibility of nurse educators to plan and manage courses in nursing in such a way that the development of reflective, knowledgeable practitioners, skilled in critical enquiry, analysis and evaluation is enhanced (Ulsenheimer, Bailey, McCullough, Thornton \& Warden, 1997:151). By doing this, the students are exposed to a situation in which they feel free to challenge routine nursing care and to explore unfamiliar areas in order to render high quality nursing care.

The question arises whether distance education can be used to foster the development of critical thinking skills of students in nursing. It is possible if the multimedia used, enable a non-linear and inductive approach to learning. Students must be enabled to take an active part in their own development and should not be taught in a linear way by lecturers. This means that lecturers in distance education have to act as facilitators and no longer as teachers (Bailey, 1992:985). Student-centered approaches instead of lecturer-centered approaches are necessary (Harden, Snowden \& Dunn, 1984:285).

\section{CRITICAL THINKING THROUGH PROBLEM- BASED LEARNING}

In developing countries with the associated problems concerning infrastructure and poverty, developing distance education programs that are affordable and enhance critical thinking is challenging. In distance education an easy way of getting students involved in learning is by letting them work on assignments, which are handed in and evaluated by the faculty. The assignments should be constructed in such a way that the students have to reflect on the care described in the critical incident or case study or reflective log that motivates critical thinking (Price, 1997:157). However, care has to be taken that evaluation of the assignment is being done in the same manner i.e. in a reflective manner and not only by means of a marking guide through which marks are allocated for facts appearing in the guide.

Problem-based learning has always been considered as a face-to-face approach in teaching. It is, however, possible to move away from the traditional way and to use it in distance education (Albanese \& Mitchell, 1993:52). With a problem-based approach the responsibility of the student as the center of the learning process is encouraged and relevancy is provided for what is learned (McMillan \& Dwyer, 1989:94). According to Ulsenheimer et al. (1997:150) there is a strong link between the skills developed through problem-solving and the skills needed for critical thinking. This is supported by Rogerson and Harden from the University of Dundee (1999:288). In reflection on their experience with distance education programs for nurses since 1991 , they indicated that problem-based learning not only nurtures self-direction but also supports critical thinking, the development of analytical skills and techniques in problem-solving. They presented problem-based learning in their distance education programs by developing course material using a wide range of clinical scenarios. Each scenario has approximately five challenges that present the student with a range of clinical 
and professional problems. The students learn by solving the challenges and focusing on the process of learning and not only on the outcome of learning (Rogerson \& Harden, 1999:289).

Problem-based learning in distance education has the advantage that it enables the student to handle difficult situations in similar ways following completion of her/his studies. Nurses working in rural areas in developing countries have to be able to solve problems on their own, as they usually do not have a support system to rely on. Through their exposure to problem-based learning they will also be able to meet the challenges of change in the situations they have to work in (Townsend, 1990:61).

As problem-based learning builds on the students existing knowledge and supports the development of a personal and conceptual knowledge base, the students are encouraged to be actively involved, which is crucial in distance education (Schmidt, 1993:422). When students are not part of an academically stimulating environment as is the case with students from rural areas, motivation to complete assignments and pitch for evaluations can be a problem.

By just following a problem-based learning approach in compiling workbooks for the students and by expecting them to do their assignments by following such an approach will, however, not be sufficient to ensure that reflective practitioners are trained. Nursing is a clinical profession with values, roles and professional practices that are developed through collaboration with the faculty, peers, experts and mentors (AACN White Paper, 2000:118). Interaction with the faculty and fellow students creates opportunities of exposure to role models (Reinert \& Fryback, 1997:426). The students who are doing postregistration courses have to develop advanced skills for the advanced professional roles expected of them on completion of the courses. For the developing of these skills and to be socialised into advanced professional roles, the availability of role models is crucial. Contact with the faculty or persons identified by the faculty who can serve as role models is so important that it has to be part of the planning of distance education programs. According to Rogerson and Harden (1999:292) the solution is a mixed mode delivery of post-registration programs for nurses with some modules delivered 'oncampus' and others by distance learning.

\section{CRITICAL THINKING THROUGH WORK- BASED LEARNING}

Integrating new theory in the real world of clinical practice through work-based learning helps the student to improve the quality of patient care and at the same time contributes to her knowledge base (Ellis, 1997:331). It closes the gap between theory and practice. Knowledge is embedded in practice and the professional development of the student is enhanced. By focusing on work-based learning the lecturers ensure that the development of nursing education is synchronized with developments in clinical practice and other changes in approaches to health care (Fyff \& Fleck, 1997:43).

Work-based learning supports the development of critical thinking skills of the students in two ways. It supports the implementation of theory in practice and it enables the students to develop skills for critical analysis and problem solving (Rogerson \& Harden, 1999:288). The latter can be initiated by exposing students to 'Think and Action' exercises. According to Wilson (1996:135), distance education is specifically suitable for work-based learning as the students are studying while continuing with their work in hospitals and clinics and by so doing they are in a position to implement what they have learned in their everyday practice. Capability learning instead of gaining knowledge is thus possible.

\section{THE NECESSITY OF STUDENT SUPPORT}

Students need support during training whether the training is being done through distance education or on campus. Although the students may be far away from the campus, it remains the responsibility of the lecturers to guide the students in adapting to the learning environment.

Attention should already have been given to the aspect of student support in the compilation of the study guide. A comprehensive and well-structured study guide can serve as an excellent support system for distance education students (Rogerson \& Harden, 1999:289). Included in the study guide must be a description of the content that will be covered, as well as guidelines for the preparation of assignments and other relevant information like the feedback system and student administration detail (Lawton, 1997:1076). Rogerson and 
Harden (1999:290) describe a well-structured study guide as a 24 hour personal tutor. Carnwell (1998:610), however, warns against a highly structured guide due to the dependence that it can foster. A balance is therefore needed between supporting students towards autonomy and creating dependence.

Not all students need the same amount of support (Cowan, 1994:59). It also varies from time-to-time and is according to the level of confidence that they have developed as well as the ability of taking responsibility for their own studies.

All students, however, have to be motivated during the course. It can best be done through face-to-face contact with faculty members (Morgan \& Morris, 1994:22). Early contact with lecturers, preferably on registration for the course, is recommended. The opportunity to meet the lecturer personalises the interaction with the university or college (Zalon, 2000:31). During this meeting the content of the study guide can be discussed and concerns that the students may have can be addressed to reduce anxiety. Although time consuming, the benefits of such a meeting can never be replaced by any other type of support. To make it feasible, a few major localities can be identified and the contact session limited to these localities only, so that the visits may be followed up at a later stage, if possible.

Contact with the faculty or representatives of the faculty (tutors) are necessary to facilitate the learning of concepts and facts, as well as for prompting reflection upon practice. Students need support in developing critical thinking skills as well as guidance with their development as reflective practitioners (Price, 1997:155). It is important that this is done at first on an individualised manner through personal contact, which can then be followed up by using a variety of different media (Lawton, 1997:1078). According to Edwards et al. (1999:40) at least one such opportunity for distant locality students to meet with the lecturer must be arranged during which time the handling of problem-based learning can be explained. This does not always have to take place at the distance localities. It can be replaced with 'residential weeks' on campus (Lawton, 1997:1078). This also serves as an important opportunity for students to get to know their fellow students and to identify who of the students live and work in a specific geographical area (Zalon,
2000:31). The latter is necessary for the establishment of student-support systems. Mutual support between students plays a vital role in the motivation of students. Not only can experiences in learning be shared but problems encountered in the implementation of theory in practice can also be shared (Rogerson \& Harden, 1999:290). This can be done either through face-to-face discussions or by telephone if facilities like other types of electronic media are not available. It is, however, important to encourage the students to use the studentto-student support systems in order to focus on the process of learning and on how to enhance it rather than focusing on the difficulties they experience (Lawton, 1997:1078). Students are able to help one another in the development of critical thinking with the support of the faculty. It has the advantage that collective professional growth can be accomplished by making use of fellow students (Lia-Hoagberg et al. 1999:118).

Bailey and Moore (1989:317) differentiate between academic support and the more pastoral aspects of support counseling. As the students in nursing who make use of distance learning are post-registration nurses, they have more demands to cope with in comparison with young, unmarried students busy with basic training in nursing. Add to this the difficulties students in developing countries have to face due to limited resources, and the pastoral support becomes even more important.

To overcome the possibility that distant students may feel isolated due to the distance from the campus, newsletters may be used to inform them about developments on campus and to distribute information about fellow students (Reinert \& Fryback, 1997:426). The arrangement of office hours for lecturers during which they are available for students to contact them, either by telephone or fax, will contribute to the accessibility of the faculty. According to Zalon (2000:32) "another possibility is to use the technology classroom for office hours immediately before and after lectures so that the students can talk face-to-face with the lecturer".

\section{LEARNING STYLES AND STUDENT SUPPORT IN DEVELOPING OF CRITICAL THINKING SKILLS}

Some students may require more support than is normally provided in distance education due to the 
approaches they follow when studying (Carnwell, 2000:1018). The so-called 'surface learners' try to remember as much as possible from the text and usually have difficulty in using distance education study guides (Marton \& Saljo, 1976:115). Students who make use of 'deep' approaches and who prefer to adapt knew knowledge to existing knowledge find it relatively easy to adapt to using distance education study guides (Jones \& Kember, 1994:93).

When distance education study guides and material are compiled in a linear sequence, holistic learners who focus on the whole rather than on small consecutive parts, may need support to adapt to the situation (Carnwell, 2000:1018). Serialist learners, who prefer to focus on detail and operations taken strictly in a linear sequence, will need less support (Pask \& Scott, 1972:212).

\section{FEEDBACK ON EVALUATION}

Students need specific comments on the strengths and weaknesses of the assignments and constructive challenges concerning that which can be improved on (Price, 1997:156). By doing this, the lecturer takes part in critical thinking and a relationship of openness develops between student and lecturer. Students must be encouraged to react on feedback from the lecturer in order to support ongoing communication. Vague comments like 'well done' have no place in developing and supporting critical thinking and must be avoided at all costs.

Having to rely on postal and courier services, special measures have to be in place in order to ensure that students receive feedback on evaluation as soon as possible and definitely before the next assignment has to be submitted. A one-stop service on the campus, responsible for management of the assignments, makes it easier to ensure that all assignments are received from the lecturers and sent to the students on time (Young, Marks-Maran \& Macklin, 1999:488).

\section{CONCLUSION AND RECOMMENDATIONS}

In many developed and developing countries, nursing education institutions make use of distance learning for various reasons. Students in cities have a choice of different institutions that offer similar programs for prospective students, whereas those colleagues who live in rural areas have to rely on distance learning. It is the responsibility of nursing education institutions to ensure that distance education is managed in such a manner that the students will not only gain knowledge, but will also gain critical thinking skills in order to enable them to develop professionally.

In order to do this the following recommendations are applicable:

- $\quad$ Problem-based learning should be implemented in order to stimulate the development of critical thinking skills.

- Work-based learning should be emphasised as a means to close the gap between nursing theory and practice.

- Contact between the lecturers and students should be organised to facilitate the development of reflective skills.

- Well-structured study guides must be compiled to render support to the students.

- $\quad$ Student-to-student support networks are necessary to create opportunities for students to participate in group discussions and should therefore be established.

- Academic and pastoral/motivational support have to be rendered to students to enable them to cope with the demands of distance learning.

- The learning styles of students have to be taken into account in the development of distance learning and teaching programs.

- Students have to receive constructive feedback on assignments.

- Effective and ongoing communication between the lecturers and the students is vital for the development of critical thinking skills.

\section{BIBLIOGRAPHY}

AACN White paper 2000: Distance Technology in Nursing Education: assessing a new frontier. Journal of Professional Nursing, 16(2):116 - 122.

Albanese, MA \& Mitchell, MA 1993: Problem-based learning: a review of literature on its outcomes and implementation issues. Academic Medicine, 68(1):52 - 80 .

Ayer, S \& Smith, C 1998: Planning flexible education to match the needs of consumers: a national survey. Journal of Advanced Nursing, 27(5):1034 - 1047. 
Bailey, D 1992: Facilitator not teacher: a role change for tutors in open learning nursing education. Journal of Advanced Nursing, 17:983 - 991.

Bailey, D \& Moore, J 1989: Closing the distance: counseling at $O U$ residential schools. Journal of Guidance and Counseling, 17(3):317 -330 .

Carnwell, R 1998: Community nurses' experiences of distance learning: implications for autonomy and dependence. Nurse Education Today, 18:610 - 615.

Carnwell, R 2000: Pedagogical implications of approaches to study in distance learning developing models through qualitative and quantitative analysis. Journal of Advanced Nursing, 31(5):1018 1028.

Cowan, J 1994: How can you assure quality in my support as a distance learner? Open Learning, 9(1):59 - 63.

Edwards, N; Hugo, K; Cragg, B \& Peterson, J 1999: The integration of problem-based learning strategies in distance education. Nurse Educator, 24(1): 36-41.

Ellis, PA 1997: Processes used by nurses to make decisions in the clinical practice. Nurse Education today, 17:325-332.

Fyffe, T \& Fleck, E 1997: Using training needs analysis to implement change. Nursing Standard, 12:43-45.

Garrison, DR 1992: Critical thinking and self-directed learning in adult education: an analysis of responsibility and control issues. Adult Education Quarterly, 42(3):136-148.

Greenwood, J 1996: Nursing theories: an introduction to their development and application. (In: J Greenwood ed. 1996: Nursing Theory in Australia: Development and Application. Addison-Wesley: Melbourne, pp. 1 -14).

Greenwood, J; Sullivan, J; Spence, K \& McDonald, M 2000: Nursing scripts and the organizational influences on critical thinking: report of a study of neonatal nurses' clinical reasoning. Journal of Advanced Nursing, 31(5):1106-1114.

Harden, RM; Snowden, S \& Dunn, WR 1984: Some educational strategies in curriculum development: the SPICES model. ASME Medical Education Booklet No 18. Medical Education, 18:284-287. Hopper, KB 2000: Are digital distance learners learning or just distant? Letter. Respiratory Care, 45(4):432-434.

Jacobs, PM; Ott, B; Sullivan, B; Ulrich, Y \& Short, L 1997: An approach to defining and operationalizing critical thinking. Journal of Nursing Education, 36(1):19-22.

Jones, A \& Kember, D 1994: Approaches to learning and student acceptance of self-study packages. Education and Training Institute, 1(2):93-97.

Laidlaw, JM \& Harden, RM 1990: What is ... a study guide? Medical Teacher, 12:7-12.

Lawton, S 1997: Supportive learning in distance education. Journal of Advanced Nursing, 25(5):1076-1083.
Leasure, AR; Davis, $L$ \& Thievon, SL 2000: Comparison of student outcomes and preferences in a traditional vs World Wide Web-based Baccalaureate Nursing Research Course. Journal of Nursing Education, 39(4):149-154.

Lia-Hoagberg, B; Vellenga, B; Miller, M \& Tao-Yuan, 1- 1999: A partnership model of distance education: students' perceptions of connectedness and professionalization. Journal of Professional Nursing, 15(2):116-122.

Marton, F \& Saljo, R 1976: On qualitative differences in learning II: outcome as a function of the learner's perception of the task. British Journal of Educational Psychology, 46:115-127.

McMillan, MA \& Dwyer, J 1989: Changing times changing paradigms (2): The Macarther experience. Nurse Education Today, 9:95-99. Morgan, D \& Morris, G 1994: The student view of tutorial support: report of a survey of Open University education students. Open Learning, 9(1):22-33.

Murphy, M 1995: Open learning: the manager's and educationalists perspective. Journal of Advanced Nursing, 21:1016-1023.

Pask, G \& Scott, BCE 1972: Learning strategies and individual competence. International Journal of Man-Machine Studies, 4:212253.

Price, B 1997: Defining quality student feedback in distance leaming Journal of Advanced Nursing, 26:154-160.

Powell, JH 1989: The reflective practitioner in Nursing. Journal of Advanced Nursing, 14:824-832.

Reilly, CE 1998: A satisfaction survey on distance education: A model for educating nurses in the Cognitive Treatment of patients with Addictive Disorders. Journal of Psychosocial Nursing, 36(7):3841.

Reinert, BR \& Fryback, PB 1997: Distance learning and nursing education. Journal of Nursing Education, 36(9):421-427.

Rogerson, ECB \& Harden, RM 1999: Seven years on: distance learning courses for first level registered nurses and midwives. Nurse Education Today, 19:286-294.

Schmidt, HG 1993: Foundations of problem-based learning: some explanatory notes. Medical Education, 27:422-432.

Shomaker, D \& Fairbank, J 1997: Evaluation of an RN-to-BSN Distance Education program via satellite for nurses in rural health care. Journal of Nursing Education, 36(7):328-330.

Sullivan, EJ 2000: Distance Education: How far can we go? (Editorial). Journal of Professional Nursing, 16(4):185-186.

Tagg, PG \& Arreola, RA 1996: Earning a Master's of Science in Nursing through distance education. Journal of Professional Nursing, 12:154-158.

Tait, A 1994: The end of innocence: critical approaches to Open and Distance Learning. Open Learning, November:27-36.

Townsend, J 1990: Problem-based learning. Nursing Times, 86:6162. 
Ulsenheimer, JH; Bailey, DW; McCullough, EM; Thornton, SE \& Warden, EW 1997: Thinking about thinking. The Journal of Continuing Education in Nursing, 28:150-156.

Von Prummer, C 1994: Women - friendly perspectives in distance education. Open Learning, February:3-12.

Wilson, J 1996: Reflective practice: a guide. Accident and Emergency Nursing, 4:135-138.

Young, G; Marks-Maran, K \& Macklin, J 1999: Developing a distance learning honours degree in health promotion for delivery using the Internet. Nurse Education Today, 19:488-494.

Zalon, ML 2000: A Prime-Time primer for distance education. Nurse

Educator, 25(1):28-33. 